
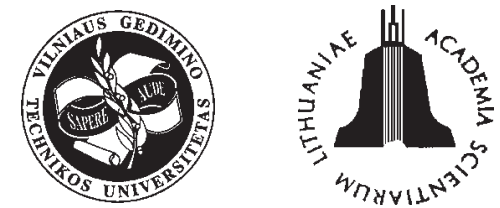

ISSN 1392-3730 print / ISSN 1822-3605 online

JOURNAL OF CIVIL ENGINEERING AND MANAGEMENT

http:/www.jcem.vgtu.lt

2006, Vol XII, No 1, 15-19

\title{
QUALITY ASSURANCE FOR HOT WATER SUPPLY FROM DH SYSTEM: SIMULATION TOOL AND APPLICATION
}

\author{
Vaclovas Kveselis ${ }^{1}$, Sigitas Masaitis ${ }^{1}$, Petras Urbonas ${ }^{2}$ \\ ${ }^{1}$ Lithuanian Energy Institute, Breslaujos g. 3, LT-44403 Kaunas, Lithuania.E-mail: vkv@mail.lei.lt \\ ${ }^{2}$ Vilnius Gediminas Technical University, Sauletekio al. 11 LT-10223 Vilnius-40, Lithuania. \\ E-mail:p.urbonas@ukmin.lt
}

Received 10 May 2005; accepted 06 Dec 2005

\begin{abstract}
Widely developed DH systems in Lithuanian towns and small settlements undergo modernisations aimed to increase their efficiency and heat supply quality. Typically, modernisations include the replacement of building heat substations, the reduction of heat losses in pipes and more efficient heat production, including the use of indigenous fuel resources. It was notified that new heat substations equipped with automatic heating control devices have backward impact on the technological parameters of DH networks. Modelling tools for simulation of hydraulic and thermal parameters in the network allow estimating of potential deviation of heat carrier temperature with loading variations not only during the season of the year, but also over day and night. Special technical measures can be taken to avoid unduly low heat carrier supply temperatures and violation of hot water supply quality requirements. Cost estimation of such measures versus the option of full network renovation is presented in the article.
\end{abstract}

Keywords: district heating (DH), domestic hot water (DHW) supply, heat supply quality, hydraulic and thermal simulation, loading patterns.

\section{Introduction}

Prevailing heat supply regulation method in $\mathrm{DH}$ supply systems recently was so-called qualitative regulation based on different heat carrier temperatures depending on outside climate conditions: air temperature, strength of wind. Constant flow mixing devices were used in building substations for lowering heat carrier temperature before it passes to the radiators. Heat exchangers for domestic hot water (DHW) heating-up typically are connected directly. Such a simple regulation of heat supply, however, needs well-balanced DH network and internal heat distribution systems in buildings. Distortions of system balance and violation of heat supply quality standards may occur due to disconnection of consumers, closing of building inlet valves, changes of hydraulic losses in interior heating devices. Installing modern building substations, equipped with automatic heating control devices and balancing of internal heat distribution systems is the solution to the problem [1]. Meanwhile, such substation not only regulates temperature and amount of heat supplied to the building, but also changes flow rate of heat carrier, passing the substation. Thus flow rate of heat carrier at the boiler-house also varies and heat supply regulation pattern becomes more complicated including both the qualitative and quantitative elements.
At the same time lower flow rates of heat carrier in the DH network during the time intervals when heat demand is reduced - eg night time in a summer - result in a bigger temperature drop in pipelines and distant consumers may receive heat carrier with a temperature lower than required by standards for DHW preparing.

Increasing supply temperature at the boiler-house, or maintaining necessary flow rate in DH network, or part of network supplying heat to such distant consumers, can prevent the problem. In both cases heat supply losses increase. Optimal solution, resulting in the lowest heat supply losses and maintaining necessary heat carrier temperatures for all consumers across the network, can be found using network simulation software tool, developed to evaluate heat loading variations of the network.

\section{Methods and assumptions}

\subsection{Heat demand variation pattern}

Real recorded heat demand pattern during the day and night of a single consumer - multi-apartment building - is a rather complicated curve, having a big number of peaks and floors (Fig 1). Heat demand depends not only on the time of day, but also is different in weekends and holidays, typically higher due to increased hot 
water consumption. Nevertheless, the number of timesteps in calculations is often limited by simulating software and is related to reasonable calculation time. On the other hand, heat carrier temperature in well-insulated pipes vary rather slowly, therefore, heat demand pattern used in this investigation is restricted by the average hourly loading intervals and is obtained by averaging recorded data.

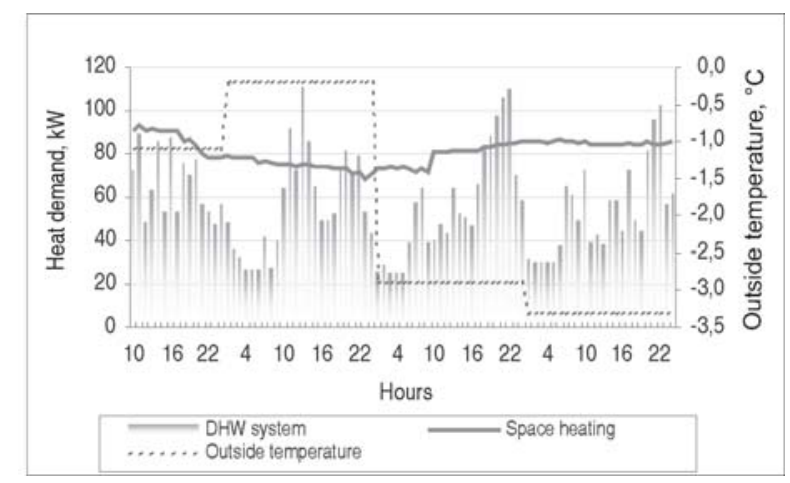

Fig 1. Recorded heat demand pattern of residential building

Data in Fig 1 illustrates hourly heat demand variation separately for space heating through radiators and for DHW system. The latter can be divided into two parts: 1) heat demand for heating-up domestic tap water and 2) for heating towel driers in bathrooms and heat losses in internal DHW pipes, heat exchangers etc. The investigation is focused on the most inconvenient heat demand pattern, when space heating is not used (summer time) and heat is supplied for covering DHW needs only. Heat demand pattern in the form of hourly loading factor used in DH network simulation is presented below (Fig 2). The loading factor shows a ratio between the actual average hourly loading and average heat demand during the day and night.

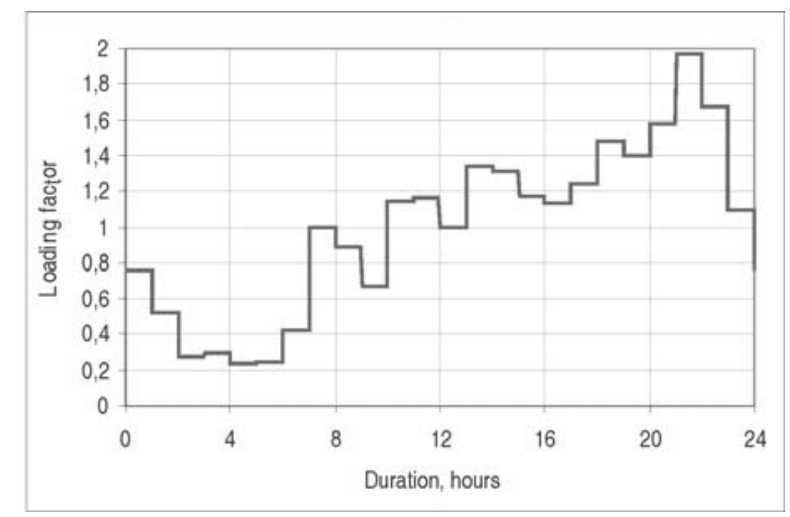

Fig 2. Heat demand pattern used for simulation

For the given building typical heat demand obtained from a decade of recorded data drops down to $23 \%$ of the average loading in midnight from 2 to $6 \mathrm{am}$, and peak demand in evening time (9-11 pm) exceeds the average by almost twice.

\subsection{Heat substations modelling}

Modern heat substations in the buildings are rather sophisticated installations often equipped with automatic control devices. Comprehensive hydraulic modelling of each consumer installation is hardly possible for larger DH systems having hundreds of consumers. In this investigation building substations are considered as automatic flow control valves, ensuring delivery of required heat amount to the building depending on supply temperature and designed temperature difference between supply and return routes. In the simulation model the following expression (1) has been used for calculation of the heat carrier flow rate passing the building substation:

$$
G=Q /\left[\rho \cdot c \cdot\left(t_{s}-t_{r}\right)\right]
$$

where:

$c$ specific heat content of heat carrier, $\mathrm{kJ} / \mathrm{kg}{ }^{\circ} \mathrm{C}$,

$Q$ actual heat demand, $\mathrm{kW}$,

$G$ heat carrier flow rate, $\mathrm{m}^{3} / \mathrm{s}$,

$t_{s}$ calculated temperature at the inlet of the building substation, considering temperature drop in supply pipelines and

$t_{r}$ designed return temperature, which should ensure proper operation of the substation.

Such an approach includes self-control: when supply temperature decreases, the flow of heat carrier automatically increases resulting in a smaller temperature drop in supply pipeline and vice versa.

Old-fashioned substations, having no automatic flow control devices are considered as general-purpose valves, which are partially closed adjusting flow rate with average heat demand value. In this case the return temperature is calculated for each loading factor value:

$$
t_{r}=t_{s}-\frac{Q}{\hat{G} \cdot \rho \cdot c},
$$

here $\hat{G}$ - pre-set flow rate depending on pressure difference between supply and return sides.

\subsection{Heat losses in the pipelines}

Heat losses in pipelines are calculated using standard heat resistance of insulation for given pipe diameter and way of installation. Real insulation values are often different from standard designed values because of ageing, flooding, damages etc. The quality of insulation is estimated by comparing design and recorded heat carrier temperatures in pipes and general network balance heat sold to consumers versus heat delivered to the network.

Iteration calculations are used for balancing both heat and hydraulic flows in the network. The method can be characterised as quasi-static for temperatures at each loading value, however real time scale is used for heat carrier transporting along the network. 
More detailed description of the used modelling software tool, its features, mathematical model and possibilities can be found in earlier publications [2-4].

\section{Object}

The object of investigation - DH system of a small town supplying heat to 25 residential buildings and to 5 other consumers - secondary school, kindergarten, municipal institutions. Total heated area of consumers is $\sim 22,000 \mathrm{sq} \mathrm{m}$. The total heat demand of consumers was $4,9 \mathrm{GWh}\left(1 \mathrm{GWh}=10^{9} \mathrm{Wh}\right)$ in 2003. The length of DH network is $2,044 \mathrm{~km}$. Boiler-house installed heat production capacity is $12 \mathrm{MW}$ (two boilers of $6 \mathrm{MW}$ each), the main fuel - natural gas. Heavy oil fuel (HOF) tanks serve as fuel reserve for reliable heat supply. All consumers have installed simple design substations with automatic heating control devices regulating the temperature of heat carrier in internal building circulating loop according to pre-set curve and depending on outside air temperatures.

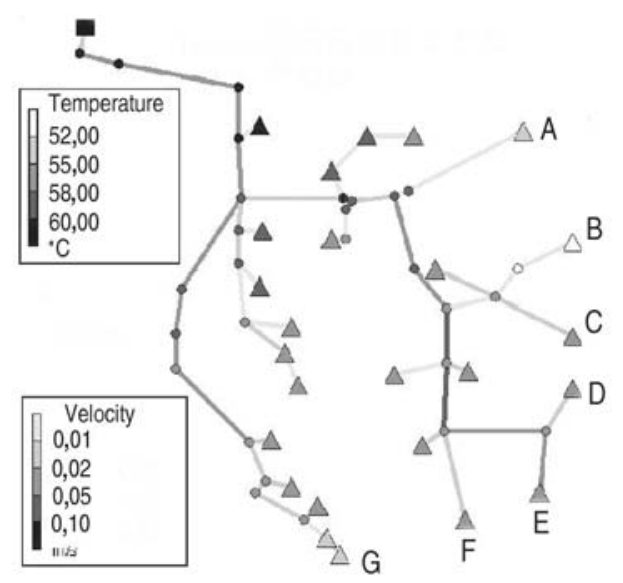

Fig 3. General design of investigated DH network

The system itself has many similarities to other small DH systems of Lithuania. It was developed during DH expansion in the 80 s and used to supply heat not only for residents, but also industry, which have collapsed during transition to the market economy. After disconnection of the big industries, the present annual linear DH network loading is only $2,4 \mathrm{MWh}$ per $1 \mathrm{~m}$ of pipeline comparing with about $5 \mathrm{MWh} / \mathrm{m}$ in Vilnius city. Maximal heating capacity demand of consumers at designed lowest outdoor temperature is 1,8 MW, and average total consumer's heat demand for DHW supply is $0,13 \mathrm{MW}$. Hence, even the capacity of one boiler exceeds maximal demand more than twice. Thus the $\mathrm{DH}$ network is under-loaded, and this is a reason for rather low heat carrier velocities in pipelines. These velocities might be lower than $0,02 \mathrm{~m} / \mathrm{s}$ at minimal loadings in some pipes. This means a long heat carrier transporting time from the boiler-house to remote consumers. Relative heat losses in pipelines in summer time, calculated as the difference of recorded consumption in buildings and heat delivered from boiler-house is up to $33 \%$.

Main attention was paid to distant consumers with highest heat losses during modelling. The letters A-G in Fig 3 mark the investigated consumers.

Prior to simulation, some technical data was collected for testing the adequacy between mathematical model and applied assumptions. Namely, recorded heat supply and return temperatures, pressures and flow rates were used as reference values. Other values - total heat demand, heat consumption for space heating and DHW of individual buildings - were used for setting base values for heat demand patterns.

\section{Results of simulation}

Results of the simulation at the above assumptions demonstrate that probability of violation of heat supply quality is rather high for distant consumers. At the same time there were no results obtained indicating disturbance of hydraulic and thermal regime for the whole DH system. Thus, supply and return temperatures remain within designed values $\left(63-33^{\circ} \mathrm{C}\right)$ regardless of significant loading and flow variations in the boiler-house (Fig 4). The calculated loading variation in the boiler-house is relatively less than the consumer's demand variation because of approximately constant additional heat demand for compensating heat losses in DH network.

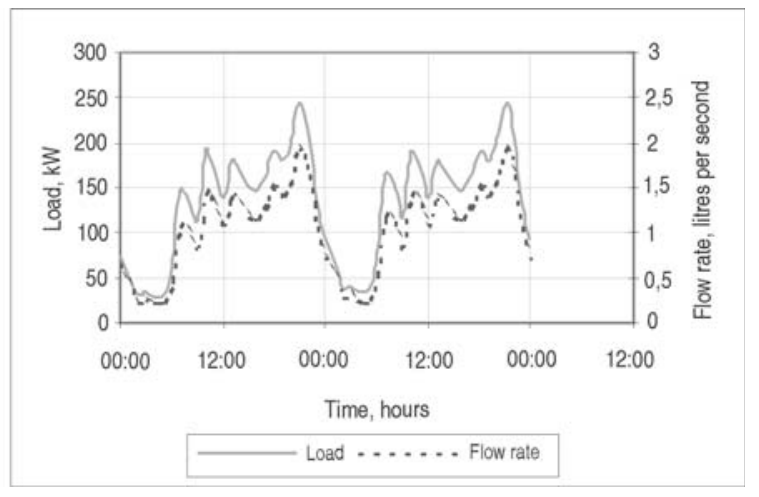

Fig 4. Loading and flow rate variation at the boiler-house

Dynamics of heat carrier temperatures delivered to distant consumers marked from "A" to "G" in Fig 2 is presented in Fig 5. Here at initial stage of simulation within time interval from 0 to 6 am thermal balance of the system is achieved starting from uniform heat carrier temperature in all pipes and consumer installations set equal to supply temperature (in this case $63^{\circ} \mathrm{C}$ ).

The lowest heat carrier supply temperature is observed at the inlet to consumer ,B”, having a low heat demand and long connecting pipelines. Other consumers having higher demand receive heat sufficient for warming-up DHW to sanitary norms (above $53{ }^{\circ} \mathrm{C}$ ) during the daytime, and only early morning heating might be insufficient. With the increase of heat demand starting from 
6 am the supply temperature quickly increases and remains at the level of $57-59{ }^{\circ} \mathrm{C}$ during the rest of the day.

It is interesting to notify different time for restoring appropriate temperatures after the low demand at nighttimes. For distant consumers the time required is from 3 to 6 hours (Fig 5). It means that they will receive DHW of lower temperature in the morning. Naturally, they have a full right to blame heat supplier for inadequate service quality as they are charged for volume of consumed DHW regardless of its temperature.

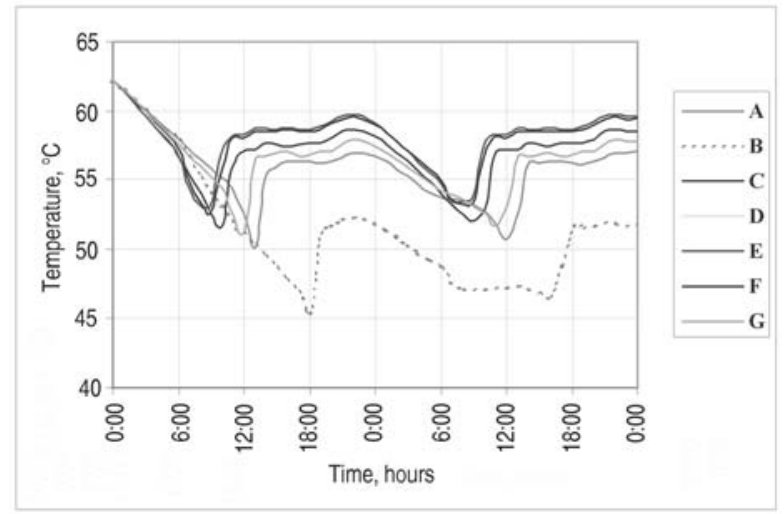

Fig 5. Heat carrier supply temperatures for distant consumers

Consumer marked "B" cannot be supplied with appropriate quality heat without special technical measures increasing flow rate in the pipeline. Replacement of oversized pipe diameter with a smaller one, calculated for actual maximal loading can be one of such measures. After replacement of $30 \mathrm{~m}$ length pipeline segment of $150 \mathrm{~mm}$ diameter to $82 \mathrm{~mm}$, heat supply quality will improve significantly (line B' in Fig 6). However, it is a rather expensive measure, and its payback will be extremely high, if only savings of heat losses are considered.

Another and a very cheap solution is to use bypass in consumer's installation allowing a higher flow rate of

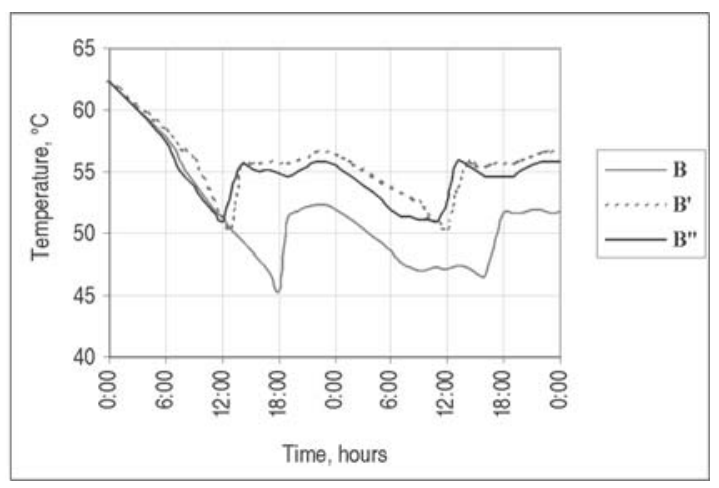

Fig 6. Effect of replacement of pipe diameter (B') and bypass (B") to temperature dynamics of supplied heat carrier heat carrier. In this case, return temperature will also increase. Required heating quality can be ensured by increasing return temperature from 35 to $45^{\circ} \mathrm{C}$ without replacement of pipelines and avoiding big investments. Supply temperature dynamics for this case is shown in Fig 6 (curve B").

Comparison of impact to the heat losses from different technical solutions aimed to avoid too low supply temperatures for distant consumers and estimated costs are presented in Table below. Increasing of supply temperature from the boiler-house would result in higher heat losses in the whole network. At $68{ }^{\circ} \mathrm{C}$ supply temperature, which should be maintained to ensure heat supply quality total heat losses in the network would be higher by $1,06 \%$. Meanwhile, replacement of pipe segment would cost $19680 \mathrm{Lt}$ and reduce heat losses by $0,64 \%$. The same goal might be achieved by increasing circulation in one specific network branch with no investment and increasing total network heat losses by only $0,06 \%$, ie negligible value.

Impact of investigated technical solutions on heat losses in the network

\begin{tabular}{l|c|c}
\hline Option & $\begin{array}{c}\text { Change of losses } \\
\text { in DH network, \% }\end{array}$ & $\begin{array}{c}\text { Investment, } \\
\mathrm{Lt}\end{array}$ \\
\hline $\begin{array}{l}\text { Increased heat supply } \\
\text { temperature from the } \\
\text { boiler-house }\end{array}$ & $+1,06$ & - \\
\hline $\begin{array}{l}\text { Replacement of } \\
\text { oversized pipe segment }\end{array}$ & $-0,64$ & 19680 \\
\hline $\begin{array}{l}\text { Increased circulation } \\
\text { (flow rate) }\end{array}$ & $+0,06$ & - \\
\hline
\end{tabular}

\section{Conclusions}

Generally, heat supply quality still remains one of the main problems, especially in small DH systems. This is a result of reduced $\mathrm{DH}$ loadings because of disconnection of big industrial the consumers and reduced DHW consumption. Insufficient heat supply quality often is one of the reasons influencing the consumer's decision to switch to another heating source, eg the individual building gas-fired boiler.

Simulation results show that for some of distant consumers qualitative heat cannot be delivered without special technical measures or reconstruction of networks.

Simulation software tool, developed by Regional energy development department at Lithuanian energy institute TINKLAS, might be useful for the identification and finding ways to deal with the problem. Proper sizing of networks is the most efficient way to ensure heat supply quality from the technical point of view. Nevertheless, other technical measures also can help dealing with a problem when replacement of pipes is not expedient due to high investment costs and high salvage value of existing pipes. The increase of flow rates for consumers situated at the endings of network branches helps enhance heating quality not only to them, but also for all 
consumers. Small increase of pumping costs is acceptable in most cases, compared to network renovation costs because the growth of pressure difference between supply and return routes in boiler-house is negligible at low flow rates and low initial flow velocities.

\section{References}

1. Kveselis, V.; Strazdas, D.; Urbonas, P. Reconstruction of heat and hot water supply system. Power Engineering (Energetika), No 1. Vilnius, 2004, p. 78-83.
2. Minkštimas, R. Modelling of energy supply networks, its elements and investigation of operating parameters. $\mathrm{PhD}$ thesis. Kaunas, 2000.

3. Minkštimas, R.; Kveselis, V.; Strazdas, D. Improvement of heat supply and distribution efficiency at too high permeability of pipelines. In: Proceedings of the int conf "Energy Efficiency, Energy Markets and Environmental Protection in the New Millennium", June 13-15, 2001, Sopron, Hungary, p. 113-119.

4. Strazdas, D.; Kveselis, V. Modelling of heat losses in DH networks. In: Proceedings of Lithuanian Science and Industry Conference 2000. Heat energy and technologies. Febr 2000. Kaunas, p. 269.

\title{
IŠ CENTRALIZUOTO ŠILUMOS TIEKIMO SISTEMOS TIEKIAMO KARŠTO VANDENS KOKYBĖS UŽTIKRINIMAS: MODELIAVIMO PROGRAMA IR JOS TAIKYMAS
}

\author{
V. Kveselis, S. Masaitis, P. Urbonas
}

Santrauka

Pastatų aprūpinimas šiluma ir karštu vandeniu iš centralizuoto šilumos tiekimo sistemų Lietuvoje - vyraujantis šilumos tiekimo būdas miestuose ir miesteliuose. Tačiau, atsijungus didelei daliai pramonès vartotojų ir sumažèjus šilumos poreikiui šildant patalpas ir karšto vandens ruošai, esamais šilumos tiekimo tinklais ne visada užtikrinama šilumos tiekimo paslaugos kokybè visiems vartotojams, ypač labiau nutolusiems nuo šilumos gamybos šaltinio. Nepalankiausias tam laikas yra vasara, kai šiluma tiekiama tik karšto vandens ruošai ir santykiniai šilumos tiekimo nuostoliai labai padidejja dèl mažo šilumos poreikio. Be to, šilumos poreikiai keičiasi ir paros metu, nakti sumažeja iki penktadalio vidutinès apkrovos. Nauji, modernūs šilumos punktai, aprūpinti automatinio srauto reguliavimo itaisais, veikia tinklais tekančio šilumnešio srautą ir, sumažèjus tekèjimo greičiui, šis ataušta dèl šilumos nuostolių per vamzdynų izoliaciją. Dèl to toli esančius vartotojus pasiekia šilumnešis, kurio temperatūra yra per žema ir neatitinka sanitarinių-higieninių normų. Vartotojų nusiskundimai dèl nepakankamos karšto vandens temperatūros patvirtina, kad ši problema realiai egzistuoja. LEI sukurta kvazidinaminio tinklų hidraulinio ir šiluminio modeliavimo programa TINKLAS bei atliktas tipiško nedidelio miestelio šilumos tiekimo modeliavimas leido nustatyti vartotojus, kuriems tiekiant karštą vandenį vasarą iškyla sunkumų. Pasiūlyti galimi techniniai sprendimai - vamzdynų skersmens pakeitimas ir iš katilinès tiekiamo šilumnešio temperatūros bei cirkuliuojančio šilumnešio srauto padidinimas. Parodyta, kad didelių investicijų reikalaujančios vamzdynų rekonstrukcijos problema gali būti laikinai išspręsta padidinant cirkuliaciją problemiškuose punktuose ir minimaliai padidinant tiekimo sąnaudas.

Raktažodžiai: centralizuotas šilumos ir karšto vandens tiekimas, tinklų hidraulinis ir šiluminis modeliavimas, kvazidinaminis modelis, šilumos tiekimo kokybè.

Vaclovas KVESELIS. Head of Regional energy development laboratory at Lithuanian Energy Institute, member of the Association of Energy Engineers. His research interests include elaboration of methods for strategic planning of regional and local energy development and provide knowledge and experience for decision-makers for sustainable development of communities.

Sigitas MASAITIS. Dipl Engineer of Regional energy development laboratory at Lithuanian Energy Institute. His postgraduate studies are devoted to solving the heat supply problems related to rapid changes in the country economics and consumers' demand, to the increase of heat supply efficiency to meet new challenges of the market economy.

Petras URBONAS. Associated Professor of Vilnius Gediminas Technical University (Dept of Heating and Ventilation). His research interests include investigation of methodologies for strategic planning of regional energy development, targeted to provide systematised sequences for decision-makers for an even development of the country economy. 